\title{
Discipleship and Postcolonial Mission: Roots and Routes in the Ongoing Quest for Identity and Vocation
}

\author{
Des Van Der Water \\ University of South Africa, South Africa
}

\begin{abstract}
Christian discipleship, which by its very nature is a call to radical witness, is inextricably linked to the 'five marks' of mission theology/praxis, namely proclamation, nurture, loving service, social transformation and care for creation.
\end{abstract}

My paper will critically examine the ways in which colonialism has impacted upon and the extent to which neocolonialism continuous to influence identity and vocation in discipleship and mission within African Christian/Church contexts in southern Africa.

Keywords: Postcolonialism, empire, mission, discipleship, African Christianity

\section{INTRODUCTION}

\subsection{The Empire (Still) Strikes Back}

The latter period of the twentieth century can rightly be regarded as the heady days of liberation from centuries of the strangle-hold of colonialism. On the continent of Africa, for instance, no less than twenty-one states shook off the yoke of colonial rule during the period 1960-1980. Yet in the early 1950s the pending demise of colonial powers in Africa was far from apparent. But 'the end when it came', observed Elizabeth Isichei, 'did so with a speed that often surprised both coloniser and colonised $^{2}$. However, while the speed at which decolonisation took place was impressive - if not spectacular -many of the hopes and dreams of those who shook off the yoke have been difficult to realise. In this regard James Darwin observes that 'decolonization in Africa was not a clean break with the imperial past, or a ticket of entry into a world of nations' ${ }^{3}$. Darwin is surely right in his assessment that the then newly established African states had inherited the weaknesses of their colonial fore-runners - into whose shoes they had stepped after the briefest of transitions ${ }^{4}$. What cannot be disputed, however, is that the advent of decolonisation engendered immense hope for the future prosperity of the continent and that independence brought immense joy to a people hungry for liberation. Guy Arnold sums up the situation and sentiments of the time as follows:

The rapid end of the European empires...all in the course of a few years and all on the same continental landmass...meant the creation of a power vacuum that was bound to lead to years of violence in the decades that followed...None of the new states was economically strong and most were economic pygmies in world terms...These problems, however, lay in the future. The immediate reaction to...independence was one of joy: freedom had been achieved at last ${ }^{5}$.

\footnotetext{
${ }^{1}$ Namely Senegal, Cote D’Ivoire, Togo, Benin, Burkina Faso, Cameroon, Gabon, Central African Republic and Congo in 1960; Sierra Leone in 1961; Uganda, Rwanda and Burundi in 1962; Malawi in 1964; The Gambia in 1965; Lesotho in 1966; Equatorial Guinea and Swaziland in 1968; Guinea Bissau in 1974; Djibouti in 1977 and Zimbabwe in 1980 (W. Woodruff, A Concise History of the Modern World: 1500 to the Present - A Guide to World Affairs [London: Abacus, 1991] 264).

${ }^{2}$ E. Isichei, A History of Christianity in Africa, SPCK: London, 1995, 323.

${ }^{3}$ J. Darwin, After Tamerlane: The Rise and Fall of Global Empire, 1400-2000, London: Penguin, $2007,467$.

${ }^{4}$ Darwin, ibid.

${ }^{5}$ G. Arnold, Africa: A Modern History, London: Atlantic, 2005, 52.
} 
In the twenty-first century we are of course squarely in the 'future' alluded to by Arnold. And given the history and ideology of Empire, it should not surprise us that well into the twenty-first century, we still concerning ourselves with colonialism. Namsoon Kang gives us a vital clue as to why this is the case when she suggests that the very reason we still concern ourselves with colonialism so many years after independence 'is that neo-colonialism has emerged and permeated every sector of people's lives without having to invade the physical territory of the colony ${ }^{6}$.

The gains of independence in the socio-political realms have been universally acknowledged notwithstanding the inevitable challenges arising from the debilitating legacies of colonialism and slavery, which dogs Africa and Africans still to this day. Moreover, we should also have anticipated that in the face of resistance against colonialism and slavery, the Empire would strike back on many fronts, would continue to invent new modes of domination and would persist in evolving ever new mutations to counter the movements of liberation. To its credit, however, the resistance against colonialism, coupled with a broad-based postcolonial movement in the Global South has had a significant - if not substantial- impact on, amongst other things, the trajectories of theology, mission and praxis. This paper will reflect upon some of these trajectories with particular reference to the missional vocation of discipleship and the issue of identity within an African Christian context.

\subsection{African Christianity - (Still) in Search of Identity}

From the perspective of Church and of Christianity, the question of identity cannot be discussed, much less resolved, apart from Christianity's imperative of vocation. By its very nature, the Christian faith embodies both identity and vocation not as separate entities but as inextricable linked.

In his provocative article, entitled 'Of Africanised bees and Africanised churches: ten theses on African Christianity" ${ }^{7}$, Tinyiko Maluleke highlights the major difficulties emanating from the term 'African Christianity' itself and with other terminologies associated with the origins and nature of Christianity in Africa. In this regard, Maluleke posits as one of his 'ten theses' the problematique that arises from thinking and writing about 'African Christianity' or 'Christianity in Africa' as a singular. Maluleke holds that in fact 'African Christianity is plural not singular ${ }^{8}$. His other nine theses are:

- Christianity has become a world religion

- The World is full of Christianities

- African Christianity exists and has always existed in dialogue

- The poor and marginalized are the overwhelming majority in African Christianity

- The Bible, Spirit and Jesus are key to understanding African Christianity

- African Christianity is confined neither to Africa nor to Africans

- Although African Christianities must not be conflated or confused with African theologies, the latter are an important window into the former

- African Christianity, like other southern Christianities, is both a potential ally and a potential hindrance to the important challenges facing the world today

- The human is the African in African Christianity ${ }^{9}$

If we concur with Maluleke's theses in general and with his third thesis in particular, namely that 'African Christianity is plural not singular', it stands to reason that any discourse on the subject has to take seriously the complexities associated with such a multi-faceted identity. One of the fundamental flaws of the nineteenth century missionary movement is precisely that it did not reckon - or reckon

\footnotetext{
${ }^{6} \mathrm{~N}$ Kang, 'Constructing Postcolonial Mission in World Christianity: Mission as Radical Affirmation', in Postcolonial Mission: Power and Partnership in World Christianity, (ed.) D. van der Water, Sopher Press: Chicago, 2010, 109

${ }^{7} \mathrm{~T}$ Maluleke, 'Of Africanised bees and Africanised churches: ten theses on African Christianity', Missionalia: Southern Africa Journal of Missiology, Vol. 38, No. 3, November 2010, 369-379.

${ }^{8}$ Maluleke, op cit, 375

${ }^{9}$ Maluleke, op cit, 375-378.
} 
seriously enough - with the non-homogenous and diverse nature of African contexts into which Christianity was implanted. Much has been written about the collaborative and complicit partnership between colonialism and Christian mission - one such being the effects of a deeply embedded eurocentric nature of Christianity in Africa. It is probably to a large extent for this very reason that the quest goes on to unearth the authentic character of Christian identity - or rather identities - within Africa. This quest has to take on board not only the ongoing challenges from the legacies of colonialism. With the emergence of neo-colonialism, the task has become even more daunting and complex than ever.

\subsection{Christianity's Roots within Africa}

The interrogation of Christian identities within Africa leads us along various trajectories. One such is to delve beyond Christianity's historical and dominant association with Europe. Thomas Oden, for instance, unearths the measure of African influence on world Christianity in, amongst other things, Christianity's intellectual formation ${ }^{10}$.Oden underlines the probable fact that it was Alexandra that played a major role in the formation of Christian theology during the time of the Early Church and was therefore an important root for ecclesiology and ecclesiastical formation:

It should not be surprising that the Christian leaders of Alexandra came to symbolize and represent all Christians on the continent in terms of ecclesiastical organization...Many Christian ideas and practices travelled north to Europe from the Nilotic and Numidian cultures. Nilotic and Numidian cultures are the epicentre for the pre-European history of Christianity ${ }^{11}$

Moreover, we should do well also to remind ourselves that the Gospel was brought to Africa by an African and that Africa has a long connection with the story of God's people. It was, after all, Egypt that provided succour to Jacob and his sons during the terrible famine in Palestine (Gen. 12:10ff), just as it did many centuries later to the Holy Family escaping the wrath of Herod (Matt.2:13ff). The Queen of Sheba figures in the story of Solomon (1 Kings 10:1ff), and Simon of Cyrene was there to carry the cross for Jesus (Matt. 27:32; Mk. 15:21; Lk. 23:26). One of the first gentile converts to the infant church is an official from Ethiopia (Acts 8:27ff). Furthermore, the measure of the growth of the Church in Africa can be seen in the importance of the Diocese of Alexandria in the first centuries and the un-equalled theological legacy of the African theologian, namely Augustine of Hippo.

It is therefore beyond dispute that Christianity in its totality has a much longer, larger and richer history than its Western or European expressions. Our quest for an authentic African Christianity therefore would be seriously flawed if we did not take on board the afore-mentioned assertion. Christianity's rootedness therefore, both within the near Eastern and subsequent African contexts which from a postcolonial point of view are Global South contexts - endow us with a much broader historical-theological and cultural basis with which to engage questions of identity. Kwame Bediako, for instance, noted that the 'southward shift of the churches' axis has given Christianity new centres of universality' ${ }^{12}$. Such an assertion seriously challenges the perpetuation of notions of hegemony. On this score, Lamin Sanneh's typology helps us to formulate a sharper and clearer critique of Western and European Christianity's hegemony. Sanneh makes a distinction between the terminology and concepts of 'Global Christianity' and 'World Christianity', stating that the former is 'the faithful replication of Christian forms and patterns developed in Europe" ${ }^{13}$. He adds that 'Global Christianity' is, in fact, the 'religious establishment and the cultural captivity of faith ${ }^{14}$ which is closely aligned to Christendom and which "carries vestiges still of that root imperial phase' ${ }^{15}$. At the core of the problem is that even in the twenty-first century there is still too much of church-planting especially in the Global South that are carbon copies of the beleaguered, failing Christendom-style church.

\footnotetext{
${ }^{10}$ T Oden, How Africa Shaped the Christian Mind: Rediscovering the African Seedbed of Western Christianity, InterVarsity Press: Illinois, 2007, 42.

${ }^{11}$ Oden, op cit, 17-18.

${ }^{12}$ K. Bediako, Christianity in Africa: The Renewal of a Non-Western Religion, Edinburgh: Edinburgh University Press, 1995, 157.

${ }^{13}$ L. Sanneh, Whose Religion is Christianity? The Gospel Beyond the West. Grand Rapids: Eerdmans, 2003,22

${ }^{14}$ Ibid.

${ }^{15}$ Ibid, 23.
} 
Regarding the terminology and concept of 'World Christianity', Sanneh is of the view that this terminology and concept 'is a movement of Christianity as it takes form and shape in societies that previously were not Christian "16. Concurring with Maluleke's view that African Christianity is 'plural not singular', Sanneh holds that 'World Christianity is not one thing, but a variety of indigenous responses through more or less effective local idioms...without necessarily the European Enlightenment frame" ${ }^{, 17}$ Given that the notions of 'African Christianity' or 'Christianity in Africa' have become an integral part of contemporary discourse we are still a long way from finding consensus on how to speak unambiguously about an identity with which the majority of African Christians resonate. The new terminology of 'World Christianity' or 'World Christianities' seem, on the surface, to present a better framework for talking about, for instance, African, Asian and for that matter also North American and European Christianity. But even the new term itself, namely 'World Christianity', is not without problem. The difficulty can be discerned when we consider that, in the North American context especially, mission studies or missiology chairs have taken on the new name of 'World Christianity' to a large extent to move away from the unwelcome colonial baggage that comes with the word 'mission'. I shall say more about the term 'mission' later.

In our search for African identity, one of the important trajectories arises from our critique of Western and European Christianity. A potential error in this regard, however, is that of 'throwing out the baby with the bathwater'. By this I mean that in our eagerness to shake off the colonial baggage that comes with Christianity from the Global North imported and imposed on Africa, we should not follow the route of discarding roots. According to Jonathan Ingleby, many of the leading postcolonial writers and thinkers are keen "to describe their "rootlessness" as an advantage rather than a curse" ${ }^{18}$. Ingleby cites, for instance, Paul Gilroy, who speaks about 'routes' rather than 'roots' to suggest that the diaspora person 'does not have secure roots which fix him (sic) in place, in a nation or an ethnic group; rather he must continually plot for himself itinerant cultural routes ${ }^{19}$.

This brings me to the heart of my contention in this paper, namely that in the final analysis, Christian identity - in whichever geographical expression and/or historical epoch - is hybrid in the best sense of the word, because the Christian faith is inherently dynamic, multi-layered and adaptable. A major part of the difficulty that Christians have been wrestling with is that identities compete with each other and that historical European and latterly North American Christianities have been presented as the superior brand from which other expressions should take their cue. In this regard, Ingleby observes:

The (Global) South, according to this psychology, is only knowable through an almost inevitable false representation...In view of this impasse...we need to develop ways of cultural interaction, of forming community, that both destroy existing oppositions and create newness, resulting in what I am going to call... 'hybridity' or 'a Third Space, 20

\subsection{The Hybridity of African Christian Identities}

I will illustrate my proposition with brief reference to the following two historical developments, one from the world of motor-vehicle technology the other from nature. These are the invention and evolution of the hybrid motor-vehicle engine and the indigenisation of the syringe tree respectively.

It may come as something of a surprise to learn that hybrid motor cars first saw the light of day as far back as the year 1898. An Austrian national by the name of Ferdinand Porsche, at the young age 23, built the first hybrid motor vehicle, using an internal combustion engine to spin a generator that provided power to electric motors located in the wheel hubs. On battery alone, the car could travel nearly 40 miles $^{21}$. Fast-forward to 1994, nearly a century after Porsche's hybrid arrived on the scene,

\footnotetext{
${ }^{16}$ Ibid, 22.

${ }^{17}$ Ibid.

${ }^{18}$ J. Ingleby, Beyond Empire: Postcolonialism\& Mission in a Global Context, Author House: Milten Keyes, $2010,118$.

${ }^{19}$ Ingleby, ibid.

${ }^{20}$ Ingleby, op cit, 100-101.

21 https://nortonsafe.search.ask.com/web?q=the+origin+and+evolution+of+hybrid+cars\&o=APN11908\&prt=cr (accessed 160516).
} 
when Akihiro Wada, executive vice president of Toyota, posed the following challenge to a special team of company engineers: build a car with double the fuel efficiency of contemporary vehicles. Three years later, Toyota introduced the Prius in Japan as the world's first mass-produced gas-electric car. Today, the Prius competes with conventional sedans as a top seller in the United States, and nearly every major carmaker in the world has either introduced hybrids or is struggling to create the technologies to make their cars more efficient ${ }^{22}$.A hybrid system in motor vehicle technology combines different power sources to maximise each one's strengths, while compensating for the other's shortcomings. Is this principle also not particularly appropriate for Global Christianity, namely that the different Christianities should abandon competing with one another but rather seek to strengthen and complement each other?

With regard to the syringe tree we may also be surprised to learn that this tree comes from Northern India and is alien to Africa. Yet these trees have taken to the soil and they weather extremely well, growing up much faster than, for instance, than many indigenous southern African trees. Having rooted itself within African soil, the alien in the syringe has undergone a good measure of adaptation and indigenisation. In theological terms it has become contextualised within Africa. If we don't know that the syringe tree is an alien species we will hardly take a second glance at the tree which stand tall and firm, providing shade against the cruel heat of the summer on the one hand and fuel to ward off the bitter cold of winter on the other. In addition, in early spring the syring as delight with their beautiful lilac blossoms. Yet they are aliens who have become indigenous.

The syringe tree symbolises the reality of boundary crossing in which one foreign and alien culture meets up with another and finds a place that the former could also experience as home. In the same way, I want to suggest that Christianity, from its Near Eastern cradle, has always had the capacity, not only to adapt, but also to thrive and flourish within the local conditions of its new habitats. Africa is one those habitats in which Christianity, not least because of its roots within African soil, has proved to be fertile environment within which the authentic plant can grow and flourish - notwithstanding the impositions and implantations of colonialism. When it comes to constructing African Christian identities we are therefore engaged with the richness of a multi-faceted and mosaic phenomenon. It stands to reason then that we search in vain for a purist or pristine 'brand' - for that matter for all Christianities - including the several hues of African Christianity.

It is therefore within the hybrid manifestations, expressions and multiple forms of Christianity that African Christians also should, perhaps paradoxically, work out their 'own salvation with fear and trembling'. And both the paradox and the challenge lies herein: Africans should do so in creative collaboration and engagement with Christians from all other global contexts. For the construction of such theological, cultural and practical hybridity not only to exist but to flourish requires, on the part of all parties concerned, humility, imagination, flexibility and inventiveness. In a contemporary newspaper article entitled, 'Who do you think you are?', Keyan Tomaselli underlines the futility of trying to cast human identity within watertight compartments, when he observes:

Identities are constructions: they are not cast in stone, pigment or language. Most of us would like to construct our own identities rather than having categories assigned to us by bureaucrats and ideologues - we don't like being told where we belong ${ }^{23}$.

Claiming one's identity in an absolute and fixed manner is, according to Kang, is therefore 'dangerous because it does not allow one to grow, evolve, multiply, or transform, ${ }^{24}$.

\subsection{Postcolonialism, Postcoloniality and Mission}

The fundamental problem therefore that we seek to address again and again is the extent to which hegemonies have equated, and not merely associated, Christianity with Christendom and with the histories and ideologies associated with capitalism, colonialism and slavery. With this particular hegemony comes, amongst other things, totalising narratives of reality. The movement and the impulses of postcolonialism and postcoloniality - notwithstanding its shortcomings as a dialectic provide an important critical paradigm in our quest for, amongst other projects, the quest for African identities that are authentic, sustainable and can stand up to rigorous scrutiny.

\footnotetext{
${ }^{22}$ http://www.nytimes.com/2007/10/24/automobiles/autospecial/24history.html?_r=0 (accessed 160516).

${ }^{23}$ Sunday Times, May 1 2016, 9.

${ }^{24}$ Kang, op cit, 108 .
} 
Postcolonial critique has laid solid foundations to help us understand, for instance, not only the colonial past but also its ongoing manifestations, as Kang has pointed out ${ }^{25}$. One of the mutations of colonialism is a shift of colonial power from European monarchy to global corporation. Our focus here, in relation to the quest for identity within African Christianity, is on the relationship between colonialism, postcolonialism and mission. With regard to the latter, precisely against the background of colonialism, it is not possible in the twenty-first century especially, to discourse on mission as if it stands free of contestation, that its meaning is obvious or self-evident, that it is no longer s site of struggle (as indeed the church still is today) and that it is something which stands alone without needing any context. Sherron K George observes that we can see how context has changed in the twenty-first century, at the very least, in the following ways:

- The Church has changed

- The missional context has changed

- The Mission Frontier has changed

- Representative Christianity is now no longer non-western ${ }^{26}$

The above assertion can be traced back to the emerging theological paradigms of the 1960's, for instance, with the title of Walter Hollenweger's book, The World is the Agenda. Hollenweger's monograph, published in 1966, reflected a major new trend in mission thinking and praxis within the inetrnational ecumenical movement, especially in the latter part of the twentieth-century. Such a book-title could easily have become a mere fashionable ecumenical slogan if its truth had not been consistently demonstrated in the ways that the Gospel message interfaces with context in every age. An example in the Gospels of the recognition that the context is critical and that the "world is the agenda' is found in the Parable of the Weeds, when Jesus explains the parable, stating that 'the field is the world' (Matt.13:38). Dietrich Bonhoeffer, when posing the iconic question 'Who is Christ for us today? ${ }^{27}$, recognised, amongst other things, that it was incumbent on every generation and every culture to engage fully with the Gospel message within its own time and within its particular context of course, against the background of the greater historical narrative of Christianity. From an African perspective, Kofi Appiah-Kubi posed the same question in the following terms:

The struggle of African theologians, scholars, and other Christians...is to find a theology that speaks to our people where we are, to enable us to answer the critical question of our Lord Jesus Christ: 'Who do you (African Christians) say that I am?'28

In regard to the relationship between post colonialism and mission, the statement in 1973 by Emilio Castro, that 'we are at the end of a missionary era: we are the very beginning of world mission, ${ }^{29}$, epitomised both the mood of the times and signalled a new era in international ecumenical mission thinking and praxis. It is important to note however that Castro's perceptive and prophetic statement did not come out of the blue. It was precipitated by several years of critical thinking and praxis on mission. For instance, in 1960 already, Stephen Neill had observed that 'the age of missions is at an end; the age of mission has begun' ${ }^{30}$. The problematic which had emerged around the term 'missions' was well explained by Carlos Cardoza-Orlandi:

\footnotetext{
${ }^{25} \mathrm{Kang}$, op cit, 109.

${ }^{26} \mathrm{~S}$. K. George, The Quest for Images of Missionaries in a 'Post-Missionary' Era, Missiology, Vol. XXX, No. 1, Jan 2002, 51-65. See also facts, figures and reflections in this regard in T. M. Johnson and S. Y. Chung, Christianity's Centre of Gravity, AD 33-2100, Global Atlas of Christianity, Edinburg University Press: Edinburgh, 2009. 50-51.

${ }^{27}$ D. Bonhoeffer, Letters \& Papers from Prison. Enlarged Edition, edited by E. Bethge, (New York: Touchstone, 1997), 279.

${ }^{28}$ K. Appiah-Kubi, 'Preface', African Theology En Route: Papers from the Pan-African Conference of Third World Theologians, December 17-23, 1977, Accra, Ghana, eds. K. Appiah-Kubi\& S. Torres, (Orbis: Maryknoll, New York, 1979), viii.

${ }^{29}$ Castro's statement was reportedly made at the Bangkok meeting of the World Council of Churches' (WCC) Commission on World Mission and Evangelism (CWME). Castro, at the time, was coming into the post as Director of Commission CWME.
}

${ }^{30}$ S. Neill cited in Bosch, op cit, 391 . 
The concept of 'missions' is often permeated by a history of a religious messianism, in which the church understood itself to be the only responsible party for the witness of the gospel. On the other hand, the objects of the gospel have often been seen exclusively as non-Christians, unsaved people. Frequently and mistakenly, no other concept or practice of mission seems to exist outside these two camps $^{31}$

The use of the term 'mission' (singular), particularly in the international ecumenical context, instead of 'missions' (plural) indicates a major two-fold shift in mission theory and praxis at the time, a shift which to this day remains pertinent. The first shift was the adoption of the term and concept of missio $D e i$, a move which signified a new understanding of mission as the sum total of God's work of creation, redemption and the consummation of all things in Jesus Christ. The concept of missio Dei has been attributed to Karl Barth, who believed that all theology, including mission, begins with God and could never be conceived as a human activity ${ }^{32}$.

It had become clear to the ecumenical world that as one era in global Christian mission had declined, a new era of post-colonial world mission had emerged. From an Asian perspective, Choan Seng Song had declared that the ecumenical world was going through an era which signalled the end of foreign missions of the church in the West, adding that this was reason for celebration because the churches of the Global South had 'at last come of age':

We formally bring to a close the era of Western foreign missions...It should take place in the midst of rejoicing - rejoicing that the Church in the Third World has at last come of age, rejoicing that now she is bold enough to declare that the final chapter of Western foreign missions has been written...Consequently a new chapter in the history of Christian mission will begin ${ }^{33}$

One of the twentieth-century post-colonial missionary organisations, the Council for World Mission $(\mathrm{CWM})^{34}$, in its attempt also to shake off the baggage of colonial-era mission, has described mission as follows:

There are many words and phrases which are used to express the nature and purpose of Christian mission. For example:

- Conversion - forgiveness - new life - eternal hope

- Reconciliation - peace - community

- Liberation - justice - humanization

- Sacrificial caring - healing - wholeness

- Preaching and teaching - baptism - church growth.

\footnotetext{
${ }^{31}$ C. F. Cardoza-Orlandi, Mission: An Essential Guide (Nashville: Abingdon Press, 2002), 14.

${ }^{32}$ Bosch, op cit, 390. Barth's influence on missionary thinking had reached its peak at the Willingen Conference of the International Missionary Council (IMC) in 1952, where mission was perceived as coming from the very nature of God. The Willingen Statement on the Missionary Calling of the Church is explicit in defining mission as primarily God's activity which is tied up with the Triune character and work of God. At the Conference, Karl Hartenstein spoke of mission as 'participation in the sending of the Son, in the missio Dei, with an inclusive aim of establishing the Lordship of Christ over the whole redeemed creation' (R. C. Bassham, Mission Theology, 1848-1975: Years of Worldwide Creative Tension, Ecumenical, Evangelical, and Roman Catholic, Pasadena, CA: William Carey Library, 1979, 332).

${ }^{33}$ C. S. Song, Christian Mission in Reconstruction: an Asian Attempt (Madras: CLS, 1975), 1.

${ }^{34}$ CWM's main predecessor, the London Missionary Society (LMS), which was founded in 1795, is widely acknowledged to have been a pioneering and ground-breaking nineteenth and twentieth-century missionary organisation. However, the LMS approach, understanding and practice of partnership were not free from the influences of colonialism, cultural imperialism and paternalism. When a decline of activity and enthusiasm had therefore set in the modern missionary era, LMS missionaries also began to withdraw from 'mission fields', especially in the wake of the call for missionary moratorium. Although the restructured CWM was constituted only in 1977, the ferment which culminated in the establishment of the new mission body had therefore begun several years earlier. (For a comprehensive history of CWM refer to D. van der Water, No Longer Strangers: A partnership in mission journey: CWM 1977-2011, unpublished manuscript).
} 
It is our belief that all these aspects of Christian mission are true to the New Testament and none can be isolated from the others and made the one controlling emphasis for all missionary work ${ }^{35}$.

In its subsequent major theological statements on mission, namely 'World Mission Today'(1999) and 'Mission in the Context of Empire' (2010), CWM consistently upholds a notion of mission as holistic and all-embracing, incorporating its multi-facets in what we have come to know as the 'five marks' or 'five faces of mission ${ }^{36}$, namely proclamation; nurture; loving service; social transformation; and care for creation. Such a holistic theology and praxis of mission allows not only for a broad-based and multi-facetted engagement in mission, it also enhances both radical discipleship and multiple identity within Christianity.

The eminent South African missiologist, David Bosch, defined 'mission' simply as 'God's "yes" to the world ${ }^{37}$ while, in the same breath, contended that as soon as one tried to define mission, one imposes a limitation on its meaning. By characterizing mission as God's 'yes' to the world, Bosch set out an understanding of mission which allows for the broadest possible theological and missiological framework. Differently stated, mission is the church's engagement with the world in a prophetic manner. In today's contexts of neo-colonialism, of systemic injustice and violence, manifested in increasing globalization of poverty, economic and social marginalisation of people and exploitation of the environment, mission as a quest for justice on a broad front is not simply an option but a mandate. Perhaps, even at the time when Bosch wrote, he was anticipating new notions of mission that were looming on the horizon, namely that theory and praxis in mission could only be understood holistically. Missiologists from the Global North have also in recent decades increasingly recognized, in an age of globalization especially, than nothing less than an holistic understanding of mission is tenable - not only in academic discourse, but also for the Church's witness and for Christian living. Andrew Kirk, for example, affirms the holistic and integrated notion by stating:

Mission is the fundamental reality of our Christian life. We are Christians because we have been called by God to work with him in the fulfilment of his purposes for humanity as a whole. Our life in this world is life in mission ${ }^{38}$.

This holistic missiology, according to George, takes on board the following 'shifts', namely from:

- the church's mission to God's mission (missio Dei)

- 'sending' to 'being sent'

- church-focussed to kingdom-focused

- doing 'for' to doing and being 'with' (solidarity)

- coming 'from above' to coming 'from below'

- mission 'out of affluence' to mission 'out of poverty'

- polarization of evangelism and social justice to holistic mission

- one-way mission to networks and mutual partnerships ${ }^{39}$

\subsection{Discipleship and Mission - The Communality of Discipleship}

Christian discipleship, in its most fundamental sense, is about following Jesus Christ into participation in God's mission in the world. Both mission and discipleship finds its inspiration and direction from

\footnotetext{
${ }^{35}$ Sharing in One World Mission, Council for World Mission, paragraph 2.2.

${ }^{36}$ The 'five marks/faces of mission' first appeared in the 1990s and have developed over several years. Originally only four, the 'marks' were first presented as part of the report of 'Working Section 1: Mission and Ministry' at the sixth meeting of the Anglican Consultative Council (ACC) in Badagry, Nigeria. A fifth 'mark' was added at the eighth meeting of the ACC in Cardiff, Wales, in view of concerns relating to the ecological crisis. The 'five marks/faces'have gained increasing acceptance in ecumenical and missiological circles worldwide.

${ }^{37}$ D. J. Bosch, Transforming Mission: Paradigm Shifts in Theology of Mission, Orbis: Maryknoll, $1991,11$.

${ }^{38}$ J. A. Kirk, What is Mission? Theological Explorations, Darton, Longman \& Todd, London, 2002, 31.

${ }^{39}$ George, op cit., 54 .
} 
the model of Jesus of Nazareth and draws its wisdom and energy from the Holy Spirit. This means, amongst things, that discipleship in all its radical import lies at the heart of the missional impulse. For its part the church, whether in Africa, Asia or the Caribbean, cannot witness credibly or participate effectively in God's mission without faithful discipleship being at the heart of its life and witness.

Christen identity within the Christendom era was assumed to be transmitted primarily through the broader culture, especially associated with the Enlightenment. For instance, one learned to be a good Christian by being a good citizen as well as a faithful family member. Today the culture can no longer be assumed to contribute constructively to Christian formation, and few families are in fact equipped to do so. Thus Christian discipleship character - and for that matter identity - must be cultivated intentionally, patiently and comprehensively by churches and Christian communities. Practices of Christian discipleship are primarily a communal reality, given the Trinitarian understandding of the imago Dei. Unfortunately, late modern culture in the Global North especially has tended to de-emphasize the communal dimension of discipleship in favour of focussing on the individual. One of the welcome developments in contemporary theology in Western Europe and

North America is the renewed attention given to practices that shape Christian life, imagination and discipleship ${ }^{40}$.

Bosch wrote that the Christianity's response to missio Dei should be to turn to God, and that to turn to God is (also) to turn to the world ${ }^{41}$. Discipleship and mission today, amongst other things, is a clarion call to the Christian community's fullest engagement with the world in a prophetic way against Empire and all its mutations, such as neo-colonialism, neo-liberal capitalism, poverty, systemic injustices, exploitation and degradation of the environment. In our day and our contexts within the Global South in particular it is my contention that rising to these challenges is not an option amongst other options - but an urgent mandate.

\section{REFERENCES}

[1] Appiah-Kubi K \& Torres S (eds.), African Theology En Route: Papers from the Pan-African Conference of Third World Theologians, December 17-23, 1977, Accra, Ghana, Orbis: Maryknoll, New York, 1979

[2] Arnold G, Africa: A Modern History, London: Atlantic, 2005

[3] Atlas of Global Christianity 1910-2010, (eds.) T.M. Johnson \& K. R. Ross, Edinburgh University Press: Edinburgh, 2009

[4] Bediako K, Christianity in Africa: The Renewal of a Non-Western Religion, Edinburgh University Press: Edinburgh, 1995

[5] Bonhoeffer D, Letters \& Papers from Prison. Enlarged Edition, edited by E. Bethge, Touchstone: New York, 1997

[6] Bosch D J, Transforming Mission: Paradigm Shifts in Theology of Mission, Orbis: Maryknoll, 1991

[7] Darwin J, After Tamerlane: The Rise and Fall of Global Empire, 1400-2000,Penguin: London, 2007

[8] Ingleby J, Beyond Empire: Postcolonialism \& Mission in a Global Context, Author House: Milten Keyes, 2010

[9] Isichei E, A History of Christianity in Africa, SPCK: London, 1995

[10] Kirk J A, What is Mission? Theological Explorations, Darton, Longman \& Todd: London, 2002

[11] Missionalia: Southern Africa Journal of Missiology, Vol. 38, No. 3, November 2010

[12] Missiology, Vol. XXX, No. 1, Jan 2002

[13] Oden T, How Africa Shaped the Christian Mind: Rediscovering the African Seedbed of Western Christianity, Inter Varsity Press: Illinois, 2007

[14] Sanneh L, Whose Religion is Christianity? The Gospel Beyond the West, Eerdmans: Grand Rapids, 2003

[15] Van der Water D P (ed.),Postcolonial Mission: Power and Partnership in World Christianity, Sopher Press: Chicago, 2010

\footnotetext{
${ }^{40}$ See M. Volf and D. C. Bass, Practicing Theology: Beliefs and Practices in Christian Life, Grand Rapids: Eerdmands, 2002, 70

${ }^{41}$ Bosch, op cit, 389-93
} 


\section{AUTHOR'S BIOGRAPHY}

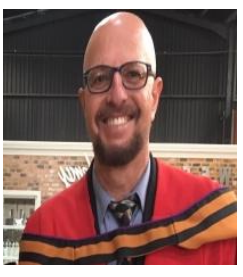

Research Fellow with the University of South Africa

Minister of Word and Sacrament in the United Congregational Church of Southern Africa.

President-Elect of the United Congregational Church of Southern Africa

Pastor of the Immanuel Congregational Church, Pretoria, South Africa

Board Member of the Theological Education by Extension College, Southern Africa

Immediate-past General Secretary of the Council for World Mission 